\title{
ANALISA PERBANDINGAN METODE FILTER GAUSSIAN, MEAN DAN MEDIAN TERHADAP REDUKSI NOISE
}

\author{
Andre Wedianto, Herlina Latipa Sari, Yanolanda Suzantri H \\ Program Studi Teknik Komputer Fakultas Ilmu Komputer Universitas Dehasen Bengkulu \\ Jl. Meranti Raya No. 32 Kota Bengkulu 38228 Telp. (0736) 22027, 26957 Fax. (0736) 341139
}

\section{ABSTRACT}

This study aimed to compare the Gaussian Method, Mean and Median in performing noise reduction using the programming language Matlab. Can make improvements in particular digital image noise reduction. Limitation of the study is a programming language used to build applications of digital image processing, especially the reduction of noise in this research Matlab programming. Digital image used jpeg extension. The method used method of Gaussian, Mean and Median. Initial image or the input image is an image that is damaged due to disturbances in image noise and generate output *.jpg. Results of the study was the result of improved image noise, especially against tampering methods used method of Gaussian, Mean and Median, of the three methods are used equally well, because all three of these methods can improve the existing noise disturbance. In doing repairs noise on digital images to note the type of interference and a good method to use. The resulting image of this improvement is relatively equal in terms of both the pixel size and the amount of file.

Keywords: Gaussian, Mean and Median

\section{INTISARI}

Penelitian ini bertujuan untuk membandingkan Metode Gaussian, Mean dan Median dalam melakukan reduksi noise dengan menggunakan bahasa pemrograman matlab. Dapat melakukan perbaikan citra digital khususnya reduksi noise. Batasan penelitian adalah Bahasa Pemograman yang digunakan dalam membangun aplikasi pengolahan citra digital khususnya reduksi noise dalam penelitian ini yaitu pemrograman Matlab. Citra Digital yang digunakan berekstensi jpeg. Metode yang digunakan Metode Gaussian, Mean dan Median. Citra awal atau citra input merupakan citra yang rusak karena gangguan pada noise citra dan menghasilkan output berupa *.jpg. Hasil penelitian adalah hasil perbaikan citra terutama terhadap gangguan noise metode yang digunakan metode Gaussian, Mean dan Median, dari ketiga metode yang digunakan sama baiknya, karena ketiga metode ini dapat memperbaiki gangguan noise yang ada. Dalam melakukan perbaikan noise pada citra digital perlu diperhatikan jenis gangguannya dan metode yang baik digunakan. Citra yang dihasilkan dari perbaikan ini relative sama baik dari segi ukuran pixel maupun besaran filenya.

Kata Kunci: Gaussian, Mean dan Median

\section{PENDAHULUAN}

Seiring dengan perkembangan teknologi di bidang komputer, baik dalam perangkat keras (hardware) maupun perangkat lunak (software), hampir sebagian besar pekerjaan manusia kini diselesaikan dengan komputer. Dengan demikian, komputer dapat dikatakan sebagai salah satu alat bantu manusia dalam menyelesaikan suatu pekerjaan Pemakaian komputer sering digunakan untuk hal-hal yang berkaitan dengan pemrosesan data (data processing), pengolahan kata (word processing), serta pengolahan gambar (image processing). Salah satu alasan mengapa komputer cenderung digunakan sebagai alat bantu dalam menyelesaikan suatu pekerjaan adalah karena pekerjaan yang dilakukan menggunakan komputer memiliki kecepatan proses yang lebih dapat diandalkan dan tidak pernah diluar prosedur kerja. Salah satu bidang yang terpengaruh adanya perkembangan teknologi komputer adalah di bidang pengolahan citra. Bidang pengolahan citra hamper ada di semua aspek kehidupan, baik untuk citra dalam kamera secara real time atau tidak real time.
Untuk mengatasi citra tersebut perlu dilakukan usaha untuk memperbaiki kualitas citra. Salah satu teknik yang digunakan adalah reduksi noise yang melakukan restorasi citra dengan cara peningkatan kualitas. Dalam reduksi noise, terdapat beberapa metode yang sering digunakan, dua diantaranya adalah Arithmetic Mean Filtering dan Median Filtering. Arithmetic Mean Filtering yang merupakan salah satu filter yang bekerja dengan menggantikan intensitas nilai pixel dengan rata-rata dari nilai pixel tersebut dengan nilai pixel-pixel tetangganya. Sedangkan Median Filtering adalah salah satu teknik filter yang mengurutkan nilai intensitas sekelompok pixel, kemudian mengganti nilai pixel yang diproses dengan nilai mediannya (nilai tengahnya).

\section{TINJAUAN PUSTAKA}

\section{A) Pengertian Analisa}

Menurut Ahmadi dan Supriyono (2006:89) analisa adalah penelusuran kesempatan atau stantangan atau sumber. Analisa juga melibatkan pemecahan suatu keseluruhan kedalam bagian-bagian untuk 
mengetahui sifat, fungsi dan saling berhubungan antar bagian tersebut. Analisa sangat diperlukan atau penting karena sifat dari lingkungan sangat dinamis dan berubah dengan cepat.

Menurut Umar (2005:42). Analisa merupakan suatu proses kerja dari rentetan tahapan pekerjaan sebelum riset didokumentasikan melalui tahapan penulisan laporan menguraikan suatu pokok menjadi beberapa bagian dan menelaah bagian itu sendiri serta hubungan antar bagian untuk memperoleh pengertian yang tepat dan pemahaman arti keseluruhan.

Berdasarkan pengertian analisa di atas, maka dapat disimpulkan bahwa analisa adalah menyelidiki, menguraikan, menelaah suatu permasalahan untuk mengetahui pemahaman yang tepat.

\section{B) Pengertian Filter Gaussian}

Menurut Usman (2005:70), filter Gaussian sangat baik untuk menghilangkan noise yang bersifat sebaran nomal, yang banyak di jumpai pada sebaran citra hasil proses digitasi menggunakan kamera karena merupakan fenomena alamiah akibat sifat pantulan cahaya dan kepekaan sensor cahaya pada kamera itu sendiri.

Gaussian Blur adalah Filter blur yang menempatkan warna transisi yang signifikan dalam sebuah image, kemudian membuat warna-warna pertengahan untuk menciptakan efek lembut pada sisi-sisi sebuah image. Gaussian blur adalah salah satu filter blur yang menggunakan rumus matematika untuk menciptakan efek autofocus untuk mengurangi detail dan menciptakan efek berkabut. Gaussian adalah istilah matematika yang diambil dari nama seorang matematikawan Jerman, Karl Friedrich Gauss.

Untuk mengatasi noise tersebut perlu dilakukan usaha untuk memperbaiki kualitas citra itu. Median filter adalah salah satu filtering non-linear yang mengurutkan nilai intensitas sekelompok pixel, kemudian mengganti nilai pixel yang diproses dengan nilai mediannya. Median filter telah digunakan secara luas untuk memperhalus dan mengembalikan bagian citra yang mengandung noise berbentuk bintik putih.

Pada penelitian terdahulu (Hwang, 1995) menjelaskan tentang dua algoritma baru untuk median filter adaptif dengan ukuran jendela variabel untuk menghilangkan impuls noise dengan kepadatan yang cukup tinggi dengan juga tetap menjaga ketajaman gambar yaitu dengan metode RAMF (Ranked-order Based Adaptive Median Filter) dan SAMF (The Impulse Size Based Adaptive Median Filter). Hasil simulasi menunjukkan bahwa kinerja dari filter ini lebih tinggi dari median filter.
Dalam penelitian lain yang dilakukan oleh (Jannah, 2008), sistem yang dibuat membahas tentang perbandingan antara tiga metode, yaitu filter Gaussian, Mean, dan Median, tetapi hanya menggunakan sampel satu buah jenis noise yaitu salt \& peppers. Pada awalnya pengguna memasukkan input data berupa citra. Citra masukan adalah citra grayscale karena sistem hanya dibatasi untuk memproses citra grayscale. Kemudian pengguna diminta untuk memasukkan parameter untuk menambahkan noise pada citra. Jika parameter telah dimasukkan, maka sistem siap melakukan proses pengurangan noise citra.

\section{C) Pengertian Filter Mean}

Menurut Usman (2005:61) salah satu filter linier adalah filter rata-rata (Filter Mean) dari intensitas pada beberapa pixel lokal dimana setiap pixel akan digantikan nilainya dengan rata-rata dari nilai intensitas pixel tersebut dengan pixel-pixel tetangganya, dan jumlah pixel tetangga yang dilibatkan tergantung pada filter yang dirancang.

Mean Filter adalah mengganti nilai pixel pada posisi $(\mathrm{x}, \mathrm{y})$ dengan nilai rata-rata pixel yang berada tetangga disekitarnya. Luasan jumlah pixel tetangga ditentukan sebagai masking/kernel/window yang berukuran misalkan $2 \times 2,3 \times 3,4 \times 4$, dan seterusnya. Kemudian akan dilakukan mean filter untuk citra $\mathrm{M}$ dengan menggunakan matriks kernel (3x3). Pixel $\mathrm{m}(2,2)=3$, akan diubah menjadi Selain mean filtering yang merupakan proses filter linier, terdapat pula pendekatan filter pembobotan (weighted filter).

\section{D) Pengertian Filter Median}

Menurut Rinaldi Munir (2004:126) menjelaskan filter median sebagai suatu jendela yang memuat sejumlah pixel ganjil. Jendela digeser titik demi titik pada seluruh daerah citra. Pada setiap pergeseran dibuat jendela baru. Titik tengah dari jendela ini diubah dengan nilai median dari jendela tersebut.

Median filter mengganti nilai suatu piksel dengan median nilai tingkat keabuan dari pixel tetangga (nilai asli piksel digunakan juga pada saat perhitungan nilai median tersebut). Media filter ini cukup popular karena beberapa tipe gangguan acak (seperti salt noise, pepper noise. Teknik ini mampu mengurangi gangguan yang lebih baik dibandingkan dengan model linear smooting dengan ukuran yang sama.

Median filter mengubah suatu titik dengan tingkat keabuan yang berbeda menjadi lebih mirip dengan tetangganya. Selain itu juga median filter mengganti nilai cluster pixel terisolasi, yang lebih terang atau gelap dibandingkan dengan pixel tetangganya serta 
luasannya kurang dari $\mathrm{n} 2 / 2$, dengan nilai median dari masking nxn. Sehingga dapat dikatakan bahwa noise yang dihilangkan akan memiliki nilai sama dengan intensitas median tetangganya.

Selain Low - Pass Filter, metode yang digunakan dalam penghalusan citra (image smoothing) adalah Median Filter. Filter ini merupakan suatu filter non linear yang dikembangkan oleh Tukey. Pada Median Filter ini suatu "window" yang memuat sejumlah pixel ganjil digeserkan titik per titik pada seluruh daerah citra.

Filter ini bekerja dengan menggantikan nilai tengah dari pixel yang dicakup oleh area filter dengan sebuah nilai tengah (median) setelah diurutkan terlebih dahulu dari yang terkecil ke yang terbesar. Biasanya ukuran filter adalah ganjil karena akan memberikan poros tengah, sehingga akan lebih mudah dalam mengolah Noise.

Kelebihan dari filter median adalah kemampuannya dalam mengurangi derau yang diakibatkan oleh derau acak misalnya jenis salt and papper noise atau bisa disebut sebagai derau impulse. Dibandingkan dengan jenis filter spasial (ruang) nonlinier lainnya, filter median merupakan filter yang paling cocok untuk kasus tersebut. Sehingga filter ini dinobatkan menjadi filter yang paling ampuh dalam mengolah citra berderau sejenis.

Dalam merancang median filter, ada beberapa hal yang harus dipersiapkan terlebih dahulu. Siapkan matriks yang akan diolah. Bila matriks berisi citra, maka jadikan citra tersebut menjadi citra grayscale atau abu-abu agar yang didapat hanya 1 matriks intensitas saja. Siapkan matriks yang NOL yang ukurannya sama persis dengan citra yang akan diolah. Matriks ini nantinya akan berisi nilai-nilai intensitas dari citra asli yang sudah diolah terlebih dahulu.

Filter max berarti menggantikan pixel dengan nilai tertinggi dari suatu deret yang terbentuk darimatriks yang sesuai dengan ukuran dari jendela filter. Langkah-langkah lainnya sama dengan filter median.

Minimum Filter merupakan kebalikan dari filter maksimum dimana pixel akan digantikan dengan nilai minimum dari sebuah deret matriks yang berukuran sesuai dengan matriks filter.

Mid-Point Filtering adalah mengganti nilai sel bitmap dengan nilai tengah diantara nilai terkecil dan terbesar dari area lokal.

Laplacian merupakan filter turunan yang fungsinya dapat mendeteksi area yang memiliki perubahan cepat (rapid changes) seperti tepi (edge) pada citra. Namun, laplacian ini sangat rentan atau sensitif terhadap kehadiran derau. Untuk itu, citra yang akan dideteksi tepinya perlu dihaluskan terlebih dahulu dengan menggunakan Gaussian. Dengan demikian dikenaladanya fungsi turunan baru yakni LOG atau Laplacian of Gaussian

Metode Sobel Merupakan metode yang menggunakan operator Sobel. Operator ini menggunakan dua buah kernel yang berukuran $3 \times 3$ pixel untuk perhitungan gradien sehingga perkiraan gradien berada tepat ditengah jendela.

Mean filter merupakan salah algoritma memperhalus citra dengan cara perhitungan nilai intensitas rata-rata citra pada setiap blok citra yang diproses. Algoritma yang umum digunakan adalah Arithmetic dan Geometric Mean Filter.

\section{E) Pengertian Reduksi Noise}

Noise adalah suatu gangguan yang disebabkan oleh penyimpanan data digital yang diterima oleh alat penerima data gambar yang dapat mengganggu kualitas citra. Noise dapat disebabkan oleh gangguan fisik (optik) pada alat penangkap citra misalnya kotoran debu yang menempel pada lensa foto maupun akibat proses pengolahan yang tidak sesuai. Ada tiga jenis noise yaitu gaussian noise, speckle noise, dan salt and pepper noise.

Noise Gaussian: modelnoise yang mengikuti distribusi normal standar dengan rata-rata nol dan standard deviasi 1. Efek dari gaussian noise ini pada gambar adalah munculnya titik-titik berwarna yang jumlahnya sama dengan persentase noise.

Noise speckle: model noise yang memberikan warna hitam pada titik yang terkena noise. Noise salt and pepper adalah bentuk noise yang biasanya terlihat titik-titik hitam dan putih pada citra seperti tebaran garam dan merica, Noise salt and pepper disebabkan karena terjadinya error bit dalam pengiriman data, pixel-pixel.

Noise pada sebuah citra dapat terjadi karena karakteristik derajat keabuan (gray-level) atau dikarenakan adanya variabel acak yang terjadi karena karakteristik Fungsi Probabilitas Kepadatan (Probability Density Function (PDF)). Apabila citra yang mengandung noise langsung diproses dan diekstrak, maka fitur-fitur pentingnya dapat menimbulkan masalah akurasi. Jadi sebaiknya citra tersebut dibersihkan dari noise terlebih dahulu, dan kemudian diproses untuk diekstrak fitur-fitur pentingnya. Salah satu teknik untuk mereduksi noise adalah order-statistics filters, yang merupakan filter spasial dimana hasil responsnya didasarkan pada pengurutan nilai piksel yang dilingkupi oleh filter (Gonzalez, 2002). 
Median filtering merupakan order-statistics filter yang paling dikenal. Cara kerja dari filter ini dirumuskan pada persamaan berikut:

$$
\mathrm{F}(\mathrm{x}, \mathrm{y})=\operatorname{median}_{(\mathrm{s}, \mathrm{t}) \text { esxy }}\{\mathrm{g}(\mathrm{s}, \mathrm{t})\}
$$

Median filtering mengambil area tertentu pada citra sesuai dengan ukuran mask yang telah ditentukan (umumnya $3 \times 3$ ), kemudian dilihat setiap nilai pixel pada area tersebut, dan nilai tengah pada area diganti dengan nilai median (Dwayne, 2000). Cara memperoleh nilai median adalah: nilai keabuan dari titik-titik pada matriks diurutkan dari nilai terkecil hingga yang terbesar, kemudian ditentukan nilai yang berada di tengah dari deret piksel.

Untuk tipe-tipe noise tertentu, filter ini memberikan kemampuan reduksi noise yang sangat baik, dengan blurring yang lebih sedikit daripada linear smoothing filter untuk ukuran citra yang sama. Median filtering memberikan hasil yang sangat bagus untuk citra yang terkena noise impulse bipolar dan unipolar. Contoh hasil reduksi noise menggunakan median filtering.

\section{F) Tinjauan Matlab}

Menurut Teguh Widiarsono (2005:1) Matlab merupakan suatu bahasa pemograman yang bisa membantu memecahkan berbagai masalah matematis yang kerap kita temui dalam bidang teknis.

Sedang menurut Muhammad Iqbal (2009:2) Matlab adalah sebuah bahasa dengan (highperformance) kinerja tinggi untuk komputasi masalah teknik. Matlab mengintegrasikan komputasi, visualisasi, dan pemrograman dalam suatu model yang sangat mudah untuk pakai dimana masalahmasalah dan penyelesaiannya diekspresikan dalam notasi matematika yang familiar.

Matlab merupakan akronim dari kata Matrix Laboratory. Versi pertama Matlab ditulis pada tahun 1970. Saat itu, Matlab digunakan untuk pelatihan dalam teori matrik, aljabar linier dan analisis numerik. Fungsi-fungsi Matlab ini digunakan untuk menyelesaikan masalah bagian khusus, yang disebut toolboxes. Toolboxes dapat digunakan untuk bidang pengolahan sinyal, sistem pengaturan, fuzzy logic, numeral network, optimasi, pengolahan citra, dan simulasi yang lain.

Matlab adalah bahasa pemrograman level tinggi yang dikhususkan untuk komputasi teknis. Bahasa ini mengintegrasikan kemampuan komputasi, visualisasi, dan pemrograman dalam sebuah lingkungan yang tunggal dan mudah digunakan. Matlab memberikan sistem interaktif yang menggunakan konsep array sebagai standar variabel elemennya tanpa membutuhkan pendeklarasian array seperti pada bahasa pemrograman lain.

\section{METODOLOGI PENELITIAN}

\section{A) Metode Penelitian}

Metode Penelitian yang digunakan dalam penyusunan skripsi ini adalah dengan menggunakan metode penelitian kuantitatif eksperimen. Metode ini bersifat validation atau menguji, yaitu menguji pengaruh satu atau lebih variabel terhadap variabel lain.

\section{B) Perangkat Keras dan Perangkat Lunak}

Adapun instrumen perangkat keras yang digunakan dalam penelitian ini adalah Personal Komputer dengan spesifikasi : Intel Pentium Core 2 Duo, Memory 4 GB, HDD 320 GB, Monitor 18", dan Keyboard + Mouse.

Perangkat lunak yang penulis gunakan dalam penelitian ini adalah Sistem Operasi Windows 7 Ultimate SP 1 dan Matlab r2013a.

\section{C) Metode Perancangan Sistem \\ 1) Blok Diagram Global}

Blok diagram global dari sistem ini adalah mengetahui perbandingan antara Metode Filter Gausian, Mean dan Median Terhadap Reduksi Noise citra digital adalah:

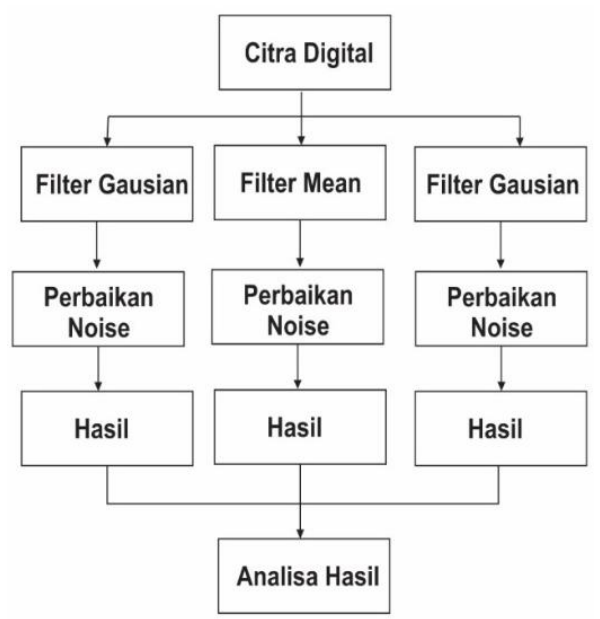

Gambar 1. Blok Diagram Global

Citra Digital merupakan gambar atau objek utama yang hendak dilakukan perbaikan

Perbaikan yang dimaksud disini adalah perbaikan (gangguan noise) terhadap citra digital.

Setelah citra digital ada dan jika ada gangguan (reduksi noise) maka selanjutnya dilakukan perbaikan. Disini ada tiga pilihan metode filter, yaitu: Filter Gausian, Filter Mean, dan Filter Median. 
Setelah filter terhadap citra digital dengan masingmasing metode yang digunakan yang selanjutnya digunakan sebagai data yang akan dibandingkan.

\section{2) Prinsip Kerja Sistem}

Prinsip kerja sistem disini bertujuan untuk memfokuskan kerja sistem yang akan di gunakan dari rancangan blok diagram yang akan dibuat dan di implementasikan sesuai dengan rancangan blok diagram dengan pokok kerja sistem. Sistem pengujian yang akan di lakukan melalui proses persiapan alat alat serta software-software yang di butuhkan, installasi pc atau laptop lengkap dengan software-software yang digunakan pada penelitian. Sampai pada akhir mendapat kesimpulan berupa hasil mana yang lebih baik melakukan filter terhadap gangguan noise pada citra digital dengan menggunakan metode filter Gausian, Mean dan Median baik itu dari segi ukuran file maupun kejelasan hasil gambar, dan faktor-faktor lain yang berhubungan dengan kwalitas filter terhadap reduksi noise lainnya.

\section{3) Rencana Rancangan Aplikasi}

Untuk melakukan filter terhadap reduksi noise disini akan dibuat sebuah aplikasi yang mampu untuk melakukan filter dengan menerapkan metode filter gausian, mean dan median dengan menggunakan bahasa pemrograman Matlab. Adapun tampilan dari rencana aplikasi yang akan dibuat untuk dapat melakukan filter terhadap reduksi noise adalah seperti pada gambar dibawah ini:

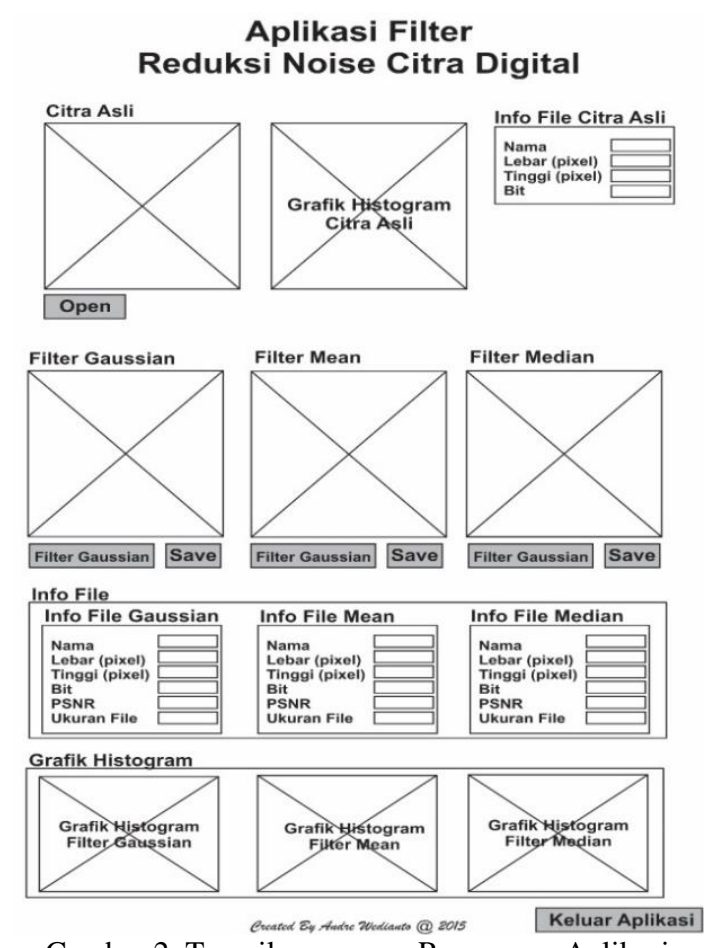

Gambar 2. Tampilan rencana Rancangan Aplikasi

\section{4) Rencana Kerja}

Perancangan rencana kerja tidak terlepas dari blok diagram yang merupakan suatu pernyataan gambar yang ringkas, dari gabungan sebab dan akibat antara masukkan dan keluaran dari suatu sistem. Adapun rencana kerja dapat dilihat pada gambar dibawah ini :

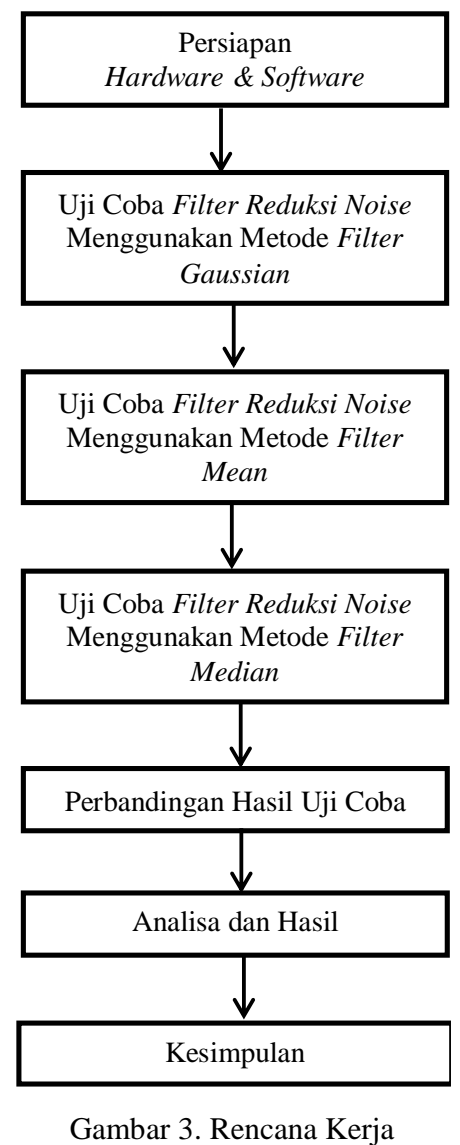

a) Persiapan

Pada tahap ini akan dilakukan atau mempersiapakan hardware, software serta kebutuhan-kebutuhan lain yang diperlukan dalam penelitian ini.

b) Uji Coba Filter reduksi Noise dengan Metode Filter Gaussian

Setelah semua tahap diatas selesai, maka dilanjutkan pada tahap uji coba. Pada tahap ini akan dilakukan uji coba menggunakan metode filter gaussian.

c) Uji Coba Filter reduksi Noise dengan Metode Filter Mean

Setelah semua tahap diatas selesai, maka dilanjutkan pada tahap uji coba. Pada tahap ini akan dilakukan uji coba menggunakan metode filter mean.

d) Uji Coba Filter reduksi Noise dengan Metode Filter Median

Setelah semua tahap diatas selesai, maka dilanjutkan pada tahap uji coba. Pada tahap ini akan dilakukan uji coba menggunakan metode filter median. 
e) Perbandingan.

Setelah itu pada tahap ini akan dilakukan perbandingan antara metode filter Gaussian, Mean dan Median. Baik itu dari segi kemudahan dalam pemakaian, implementasi sampai dengan hasil yang dihasilkan dari pada proses filter (perbaikan) Reduksi Noise pada Citra Digital.

f) Analisa dan Hasil.

Pada akhir pembahasan didapat hasil berupa kelebihan dan kekurangan dari masing-masing metode filter dan setelah itu dilakukan pengambilan kesimpulan sehingga didapatkan informasi tentang hasil perbandingan metode filter Gaussian, Mean dan Median untuk melakukan perbaikan (filter) terhadap Reduksi Noise pada Citra Digital.

\section{g) Kesimpulan}

Dan sampailah pada tahap akhir pengambilan kesimpulan yaitu untuk menentukan mana yang lebih baik dari pada masing-masing metode filter yang digunakan.

\section{5) Rencana Pengujian}

Adapun rencana atau instrument-instrument yang akan penulis lakukan pengujian secara garis besar dalam penelitian ini adalah sebagai berikut:

a) Kemampuan dari Metode filter Gaussian

b) Kemampuan dari Metode filter Mean

c) Kemampuan dari Metode filter Median

\section{PEMBAHASAN}

\section{A) Hasil}

Tahap pengujian ini penulis mendapatkan hasil dari penggunaan matlab r2013a dalam melakukan filter noise dari masing-masing metode yang digunakan dalam penelitian ini. Seperti pada gambar berikut ini.

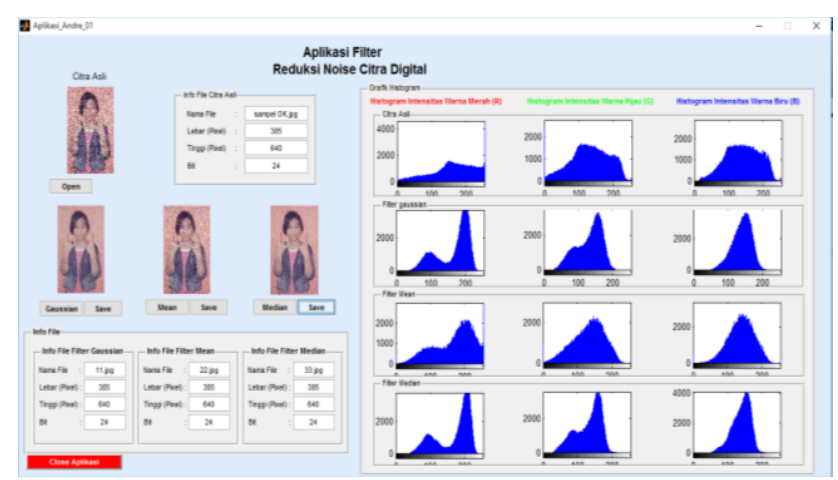

Gambar 4. Tampilan Aplikasi Reduksi Noise

Dari gambar 4 dapat dilihat bahwa gambar hasil dari reduksi noise lebih cerah dan jelas kelihatan oleh mata dari pada gambar asli mendekati sama (dilihat dengan langsung dengan mata), karena reduksi noise akan menghilangkan noise-noise yang menggangu dari pada sebuah citra digital.

B) Aplikasi Reduksi Noise Menggunakan Matlab dengan metode Gaussian, Mean dan Median

Berikut adalah hasil dari pembuatan dari pada aplikasi dengan menggunakan matlab.

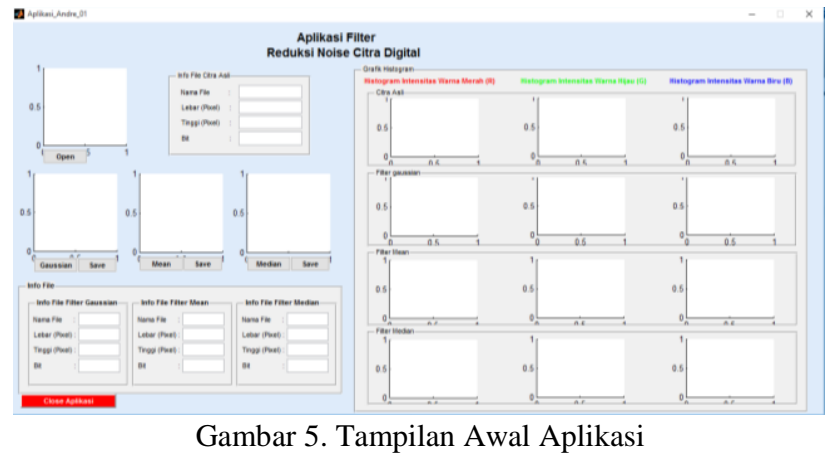

Setelah Open File klik maka akan muncul dialog seperti berikut ini :

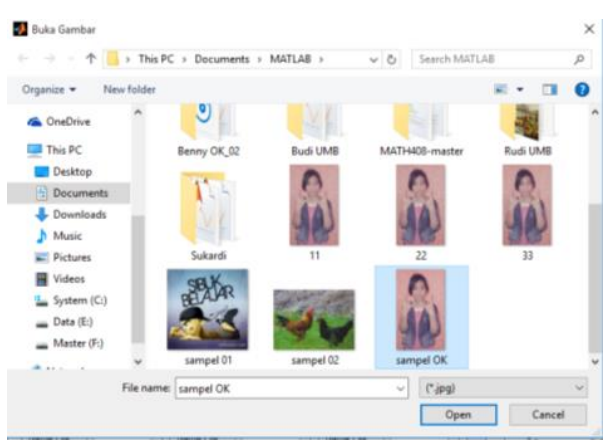

Gambar 6. Tampilan Pilihan File

Yang mana pada tahap ini akan melakukan pemilihan atau pengambilan citra awal yang hendak disisipkan dengan citra lain atau pesan. Maka setelah itu pilih file gambar yang akan di olah maka selanjutnya akan muncul gambar pada tempat yang telah disediakan seperti pada gambar berikut ini :

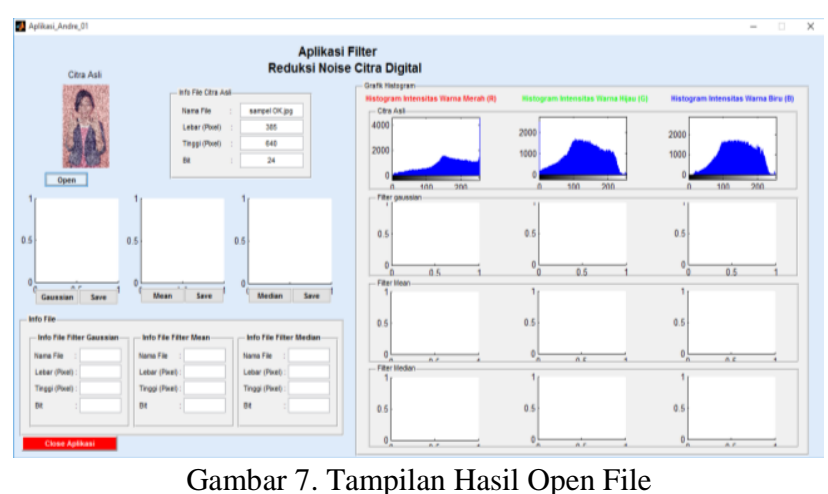

Itulah semua proses open file yang dilakukan pada aplikasi yang penulis rancang dan buat ini dilakukan secara berurutan. Jika tidak dilakukan secara berurutan atau belum ada citra yang akan diproses. 
Selanjutnya melakukan filter citra dengan metode Gaussian, Metode Mean dan Metode Median. Untuk melakukan filter noise ini dilakukan secara bergantian. Setalah diklik button Gaussian, Mean dan Median maka pada hasil akan muncul tampilan gambar yang sama dengan Citra Asli akan tetapi telah disisipkan dengan gambar lain.

\section{1) Metode Gaussian}

Untuk melakukan filter noise dengan metode gaussian silakan klik button Gaussian seperti pada gambar dibawah ini :

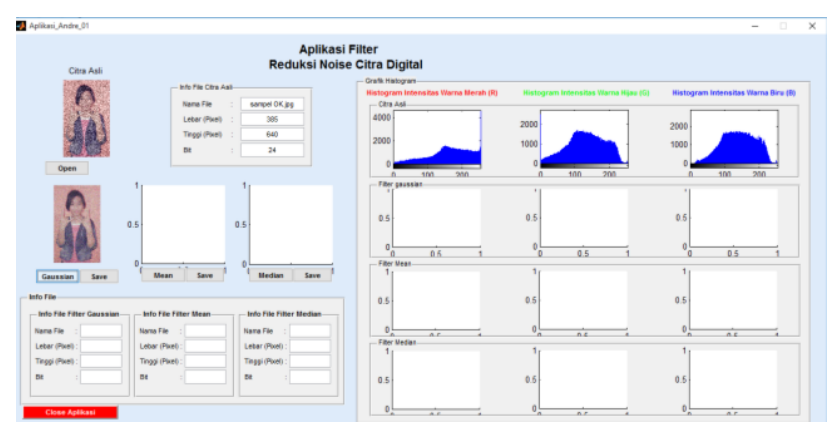

Gambar 8. Tampilan Hasil Reduksi Noise Metode Gausian

Dalam melakukan save file dapat dilakukan dengan melakukan klik pada tombol save yang ada pada masing-masing metode, setelah muncul dialog selanjutnya setelah klik save, dilanjutkan dengan memberi nama file dan lokasi penyimpanan sesuai dengan keinginan. Dan terakhir akan mendapatkan sebuah file hasil pengolahan citra digital dengan nama hasil *.jpg seperti pada gambar berikut ini :

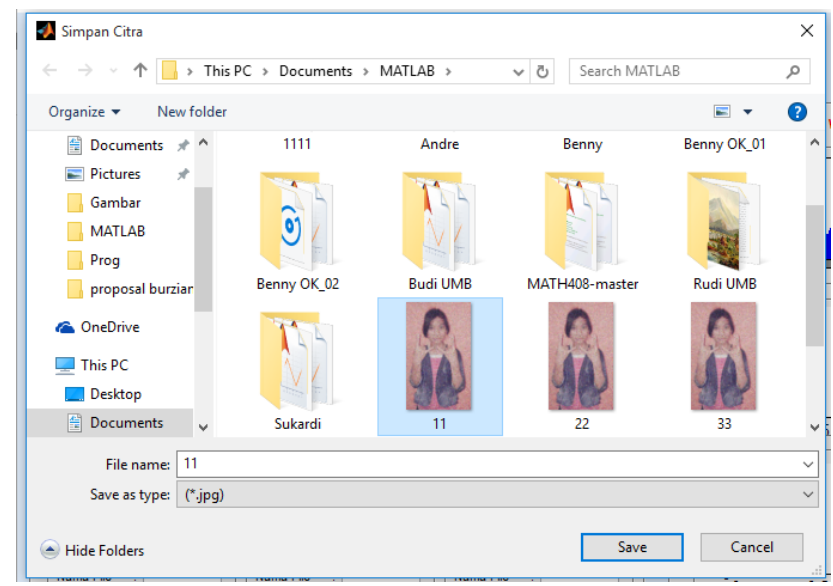

Gambar 9. Tampilan Save File Metode Gausian

Setelah file hasil filter noise menggunakan metode gaussian berhasil disimpan maka pada aplikasi akan muncul secara otomatis tampilan histogram dari gambar hasil filter gaussian, seperti pada gambar berikut ini :

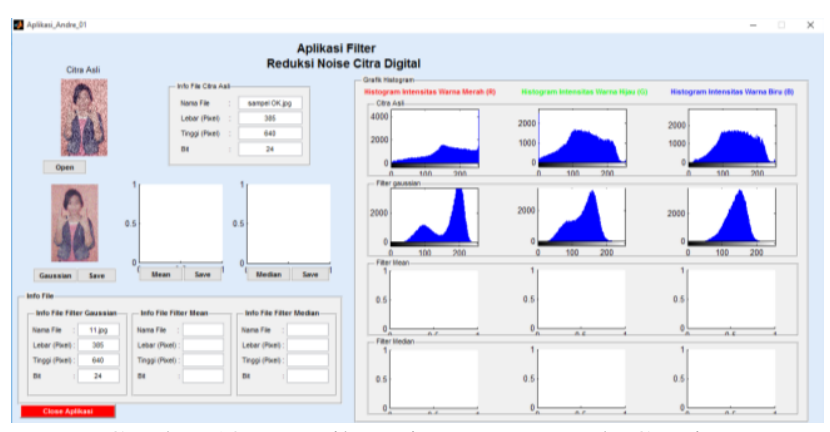

Gambar 10. Tampilan Histogram Metode Gausian

\section{2) Metode Mean}

Untuk melakukan filter noise dengan metode Mean silakan klik button Gaussian seperti pada gambar dibawah ini :

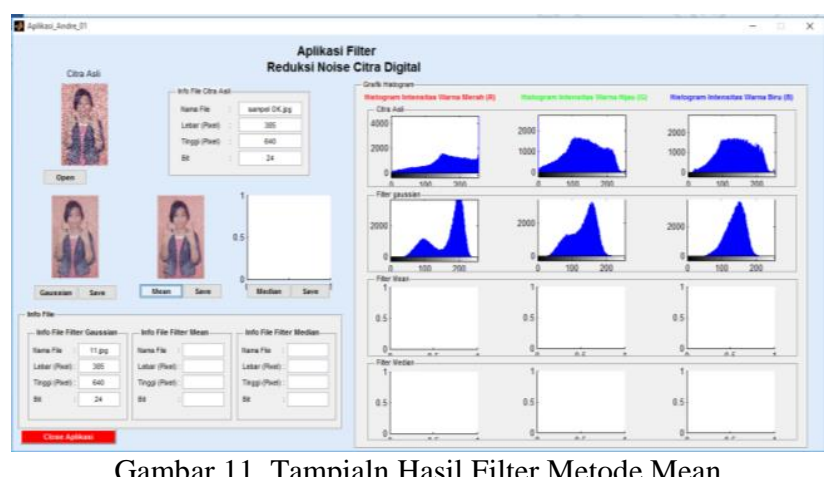

Dalam melakukan save file dapat dilakukan dengan melakukan klik pada tombol save yang ada pada masing-masing metode, setelah muncul dialog selanjutnya setelah klik save, dilanjutkan dengan memberi nama file dan lokasi penyimpanan sesuai dengan keinginan. Dan terakhir akan mendapatkan sebuah file hasil pengolahan citra digital dengan nama hasil *.jpg seperti pada gambar berikut ini :

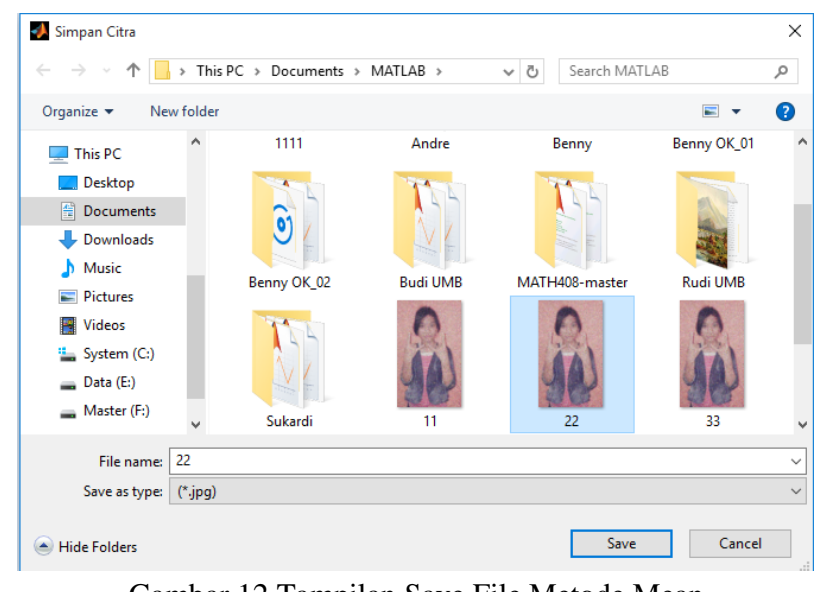

Gambar 12.Tampilan Save File Metode Mean

Setelah file hasil filter noise menggunakan metode mean berhasil disimpan maka pada aplikasi akan muncul secara otomatis tampilan histogram dari 
gambar hasil filter mean, seperti pada gambar berikut ini :

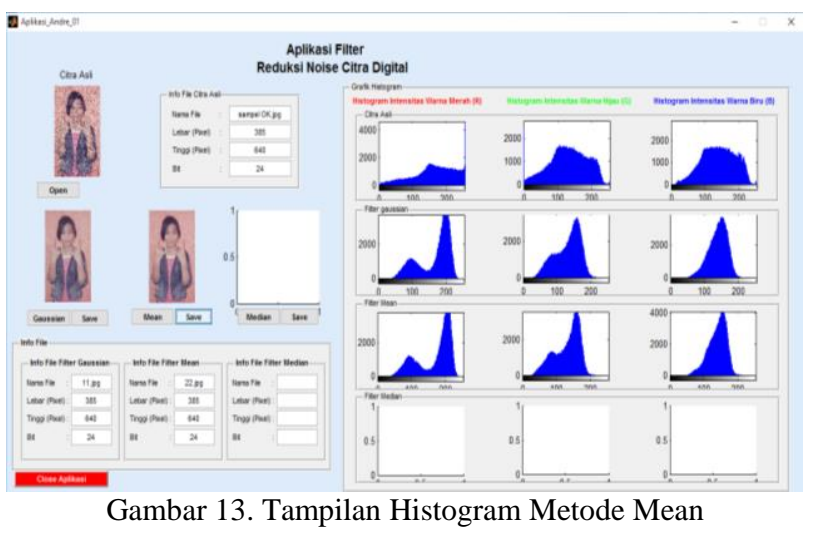

\section{3) Metode Median}

Untuk melakukan filter noise dengan metode median silakan klik button median seperti pada gambar dibawah ini :

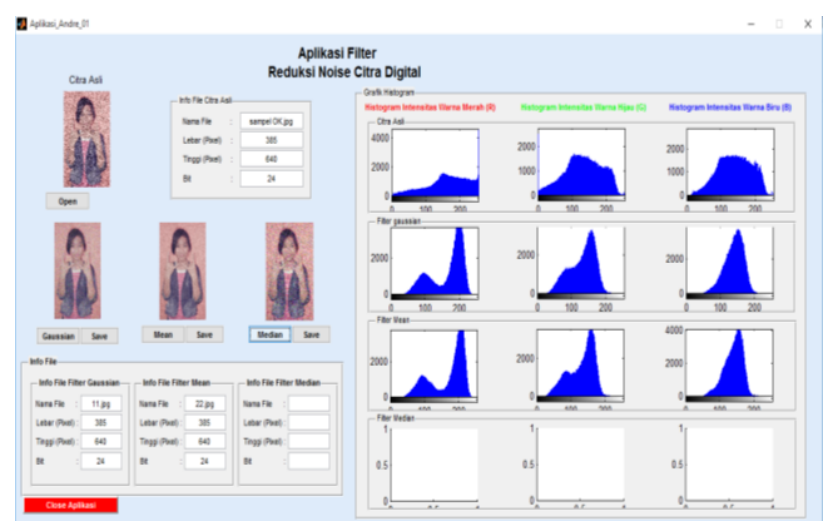

Gambar 14. Tampilan Hasil Reduksi Noise Metode Median

Dalam melakukan save file dapat dilakukan dengan melakukan klik pada tombol save yang ada pada masing-masing metode, setelah muncul dialog selanjutnya setelah klik save, dilanjutkan dengan memberi nama file dan lokasi penyimpanan sesuai dengan keinginan. Dan terakhir akan mendapatkan sebuah file hasil pengolahan citra digital dengan nama hasil *.jpg seperti pada gambar berikut ini :

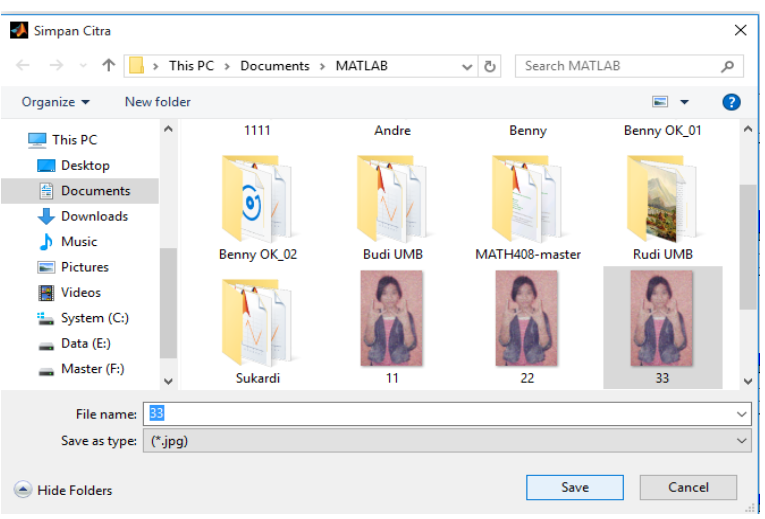

Gambar 15.Tampilan Save File Metode Median
Setelah file hasil filter noise menggunakan metode media berhasil disimpan maka pada aplikasi akan muncul secara otomatis tampilan histogram dari gambar hasil filter median, seperti pada gambar berikut ini :

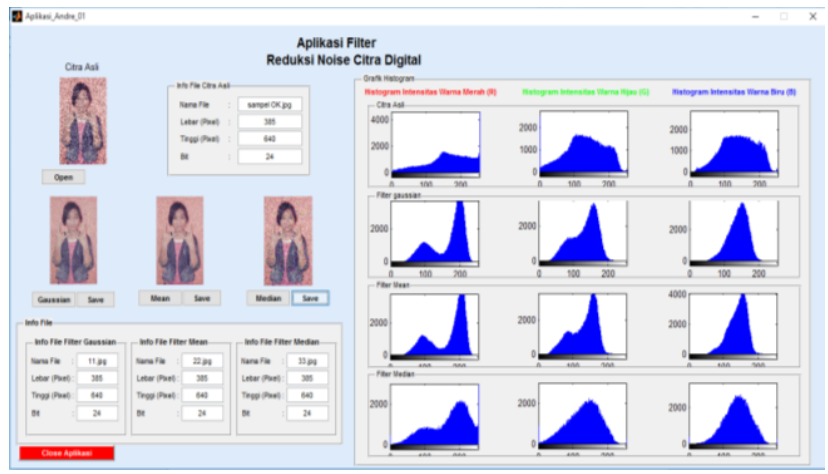

Gambar 16. Tampilan Hostogram Metode Median

Setelah gambar hasil filter noise dengan semua metode disimpan maka akan muncul tampilan informasi gambar hasil filter noise, seperti yang ditandai dengan kotak merah pada gambar berikut ini:

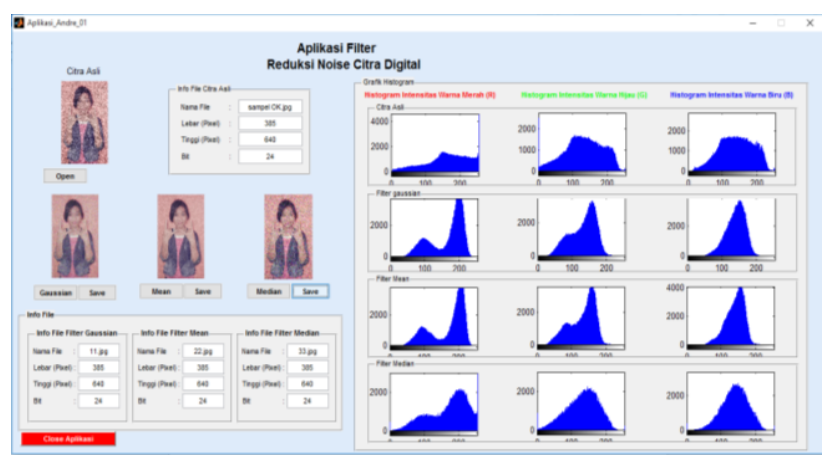

Gambar 17. Tampilan Info File

Setelah semua proses filter noise selesai dilakukan maka untuk keluar dari aplikasi ini dengan mengklik tombol close, yang mana setelah klik tombol close maka aplikasi akan memberitahukan apakah akan keluar dari aplikasi atau tidak berupa munculnya dialog atau popup. Seperti pada gambar berikut ini :

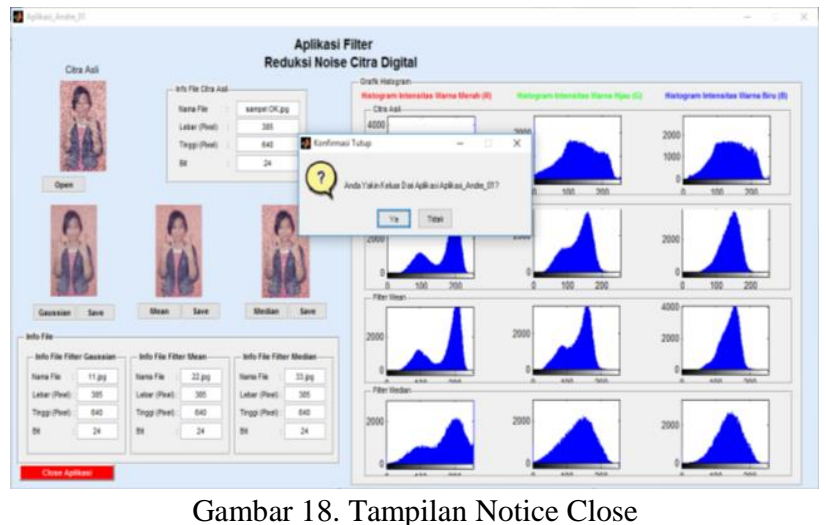

Gambar 18. Tampilan Notice Close 
Pada proses close dari aplikasi ini berupa munculnya notice pemberi tahuan apakah keluar atau tidak. Jika di klik ya maka akan keluar dari aplikasi dan jika tidak akan kembali ke aplikasi.

\section{C) Hasil Pengujian}

Dari analisa dan pengujian yang penulis lakukan penulis dapatkan hasil seperti Tabel 1 dan 2.

Tabel 1. Recana Pengujian Filter Gausian

\begin{tabular}{|c|c|c|c|c|c|c|c|}
\hline \multirow{2}{*}{ No } & \multirow{2}{*}{ Sampel } & \multicolumn{5}{|c|}{ Hasil } & \multirow{2}{*}{ Ket } \\
\cline { 3 - 6 } & & \multicolumn{2}{|c|}{ Pixel } & Bit & Ukuran & Kecerahan & \\
\cline { 3 - 7 } & & Lebar & Tinggi & & & & \\
\hline 1 & Sampel01.jpg & 385 & 680 & 24 & $46 \mathrm{~Kb}$ & Cerah & Baik \\
\hline 2 & Sampel02.jpg & 450 & 550 & 24 & $69 \mathrm{~Kb}$ & Cerah & Baik \\
\hline 3 & Sampel03.jpg & 258 & 720 & 24 & $128 \mathrm{~Kb}$ & Cerah & Baik \\
\hline 4 & Sampel04.jpg & 368 & 620 & 24 & $255 \mathrm{~Kb}$ & Cerah & Baik \\
\hline 5 & Sampel05.jpg & 478 & 782 & 24 & $389 \mathrm{~Kb}$ & Cerah & Baik \\
\hline
\end{tabular}

Tabel 2. Hasil Pengujian Berdasarkan Kecerahan Citra

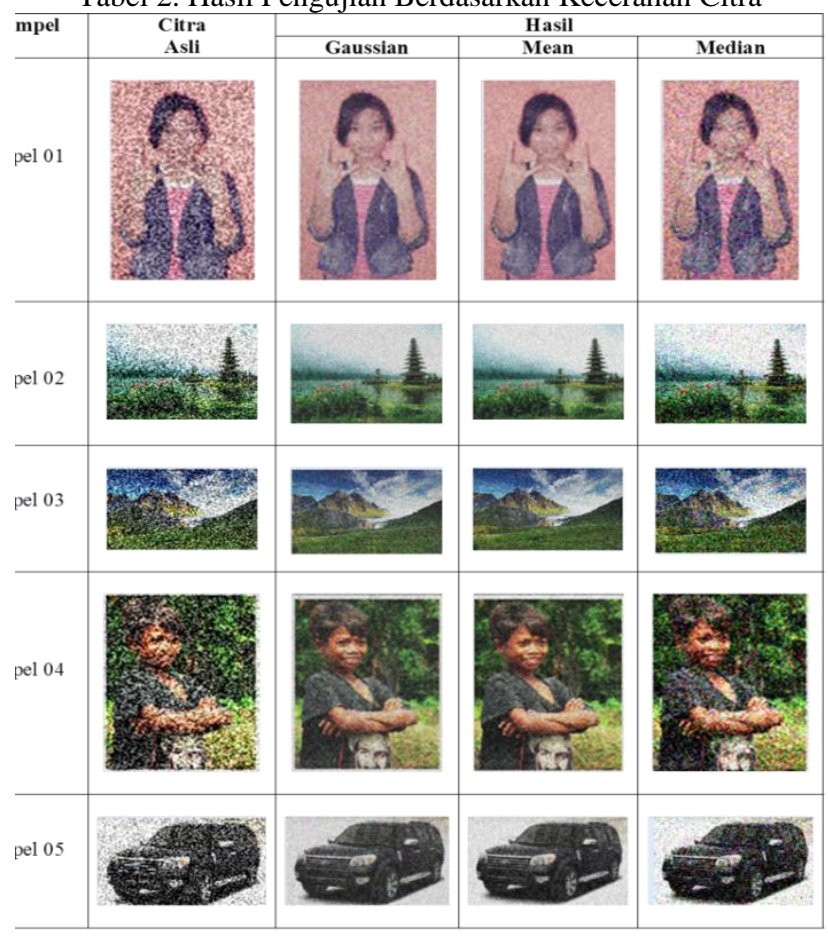

Dari hasil pengujian berdasarkan lima buah sampel citra yang rusak karena reduksi noise dapat dilihat bahwa perbaikan citra yang rudak karena reduksi noise dengan menggunakan metode Mean lebih baik dari pada metode Gaussian dan Median. Hal itu dapat dilihat dari kecerahan citra yang dihasilkan dan citra yang dihasilkan lebih focus.

Tabel 3. Rencana Pengujian Filter Mean

\begin{tabular}{|c|c|c|c|c|c|c|c|}
\hline \multirow{2}{*}{ No } & \multirow{2}{*}{ Sampel } & \multicolumn{5}{|c|}{ Hasil } & \multirow{2}{*}{ Ket } \\
\cline { 3 - 6 } & & \multicolumn{2}{|c|}{ Pixel } & Ukuran & Kecerahan & \\
\cline { 3 - 6 } & & Lebar & Tinggi & & & & \\
\hline 1 & Sampel01.jpg & 385 & 680 & 24 & $46 \mathrm{~Kb}$ & Cerah & Baik \\
\hline 2 & Sampe102.jpg & 450 & 550 & 24 & $46 \mathrm{~Kb}$ & Cerah & Baik \\
\hline 3 & Sampe103.jpg & 258 & 720 & 24 & $46 \mathrm{~Kb}$ & Cerah & Baik \\
\hline 4 & Sampel04.jpg & 368 & 620 & 24 & $46 \mathrm{~Kb}$ & Cerah & Baik \\
\hline 5 & Sampel05.jpg & 478 & 782 & 24 & $46 \mathrm{~Kb}$ & Cerah & Baik \\
\hline
\end{tabular}

Tabel 4. Rencana Pengujian Filter Median

\begin{tabular}{|c|c|c|c|c|c|c|c|}
\hline \multirow{2}{*}{ No } & \multirow{2}{*}{ Sampel } & \multicolumn{5}{|c|}{ Hasil } & \multirow{2}{*}{ Ket } \\
\cline { 3 - 6 } & & \multicolumn{2}{|c|}{ Pixel } & Ukuran & Kecerahan & \\
\cline { 3 - 6 } & & Lebar & Tinggi & & & & \\
\hline 1 & Sampel01.jpg & 385 & 680 & 24 & $46 \mathrm{~Kb}$ & Cerah & Baik \\
\hline 2 & Sampel02.jpg & 450 & 550 & 24 & $46 \mathrm{~Kb}$ & Cerah & Baik \\
\hline 3 & Sampel03.jpg & 258 & 720 & 24 & $46 \mathrm{~Kb}$ & Cerah & Baik \\
\hline 4 & Sampel04.jpg & 368 & 620 & 24 & $46 \mathrm{~Kb}$ & Cerah & Baik \\
\hline 5 & Sampel05.jpg & 478 & 782 & 24 & $46 \mathrm{~Kb}$ & Cerah & Baik \\
\hline
\end{tabular}

Dalam melakukan Reduksi Noise terhadap citra digital dengan menggunakan metode Gaussian, Mean dan Median dapat dilihat hasil perbandingan dengan melihat grafik histogram yang menampilkan komposisi warna RGB (Red, Green dan Blue), seperti dapat dilihat pada gambar dibawah ini:

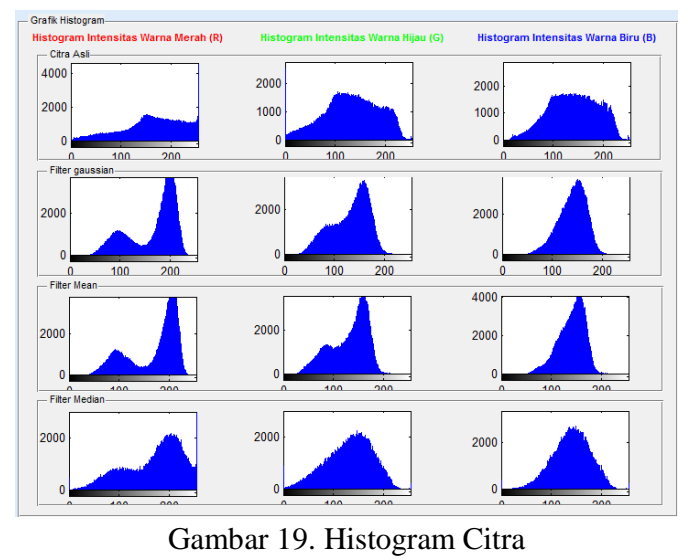

Dari gambar diatas dapat dilihat bahwa perbaikan terhadap Reduksi Noise pada citra digital dengan menggunakan metode mean lebih baik. Karena metode mean akan mengambil nilai rata-rata dari semua nilai pixel yang ada untuk mengantikan nilai pixel yang rusak.

\section{PENUTUP}

\section{A) Kesimpulan}

Dari pembahasan skripsi tentang reduksi noise dengan menggunakan metode Gaussian, Mean dan Median, maka penulis dapat menyimpulkan:

1) Penggunaan grafik histogram dalam pengolahan citra digital digunakakan untuk dapat membandingkan penyebaran warna hasil dengan warna asli, khususnya dalam melakukan reduksi noise berguna untuk melihat penyebaran warna, khususnya RGB (Red, Green dan Blue).

2) Citra digital yang telah dilakukan reduksi noise dengan menggunakan metode Gaussian, Mean dan Median akan menghasilkan kecerahannya dan kualitas gambar yang lebih baik dari citra digital aslinya. Akan tetapi tidak akan merupah ukuran file dan pixel dari citra.

3) Penggunaan masing-masing metode (Gaussian, Mean dan Media) sebaiknya digunakan sesuai 
dengan jenis kerusakan pada citra, khususnya gangguan noise dari pada citra.

4) Dari hasil penelitian yang dilakukan Metode Mean lebih baik dalam melakukan perbaikan (Reduksi Noise) terhadap citra digital, karena dengan menggunakan Metode Mean akan menghasilkan citra yang lebih focus disebabkan oleh dalam pengantian nilai pixel menggunakan nilai rata-rata dari semua nilai yang ada.

\section{B) 5.2 Saran}

Setelah dilakukan pengujian terhadap aplikasi pengolahan citra digital dengan menggunakan Matlab R2013a sebagai bahasa pemogramannya maka penulis menyarankan :

1) Untuk penelitian dimasa datang metode Gaussian, Mean dan Median dapat digunakan untuk keperluan dunia kesehatan seperti dapat memperbaiki secara otomatis cita hasil Rontgen, Hasil USG dan keperluan lainnya.

2) Aplikasi pengolahan citra digital khususnya reduksi noise dengan menggunakan metode Gaussian, Mean dan Median ini dapat dikembangkan lagi seperti dengan menambah fasilitas Crop, Rotate dan lainnya.

\section{DAFTAR PUSTAKA}

Ahmad, Usman. 2005. Pengolahan Citra Digital dan Teknik Pemrogramannya. Edisi Pertama. Yogyakarta: Graha ilmu

Ahmadi dan Supriyono. 2006. Psikologi Belajar. Jakarta: Rineka Cipta

Gonzales, R.C., and Woods, R.E. 2002. Digital Image Processing with Matlab : 2nd edition. New Jersey: Prentice Hall.

Husein Umar, 2005. Metode Penelitian. Jakarta: Salemba Empat

Jogiyanto. 2004. Pengenalan Komputer, Dasar Ilmu Komputer, Pemrograman, Sistem Informasi dan Intelegensi Buatan. Andi. Yogyakarta

Muhammad Iqbal. 2009. Pengolahan Citra Digital Menggunakan Matlab.

Munir, Rinaldi. 2004. Pengolahan Citra Digital Dengan Pendekatan Algoritmik. Bandung: Informatika.

Teguh Widiarsono, M.T. 2005. Tutorial Praktis Belajar Matlab. Jakarta 